\title{
Üniversite Öğrencilerinin Uzaktan Öğretime ilişkin Metaforik Algıları
}

\author{
Dr. Öğr. Üyesi Nesip Demirbilek \\ Bingöl Üniversitesi-Türkiye \\ ndemirbilek@bingol.edu.tr
}

\begin{abstract}
Özet:
Bu araştırmanın amacı üniversite öğrencilerinin uzaktan öğretim kavramı hakkındaki düşüncelerini metaforlar aracılığı ile nasıl kavramsallaştırdıklarını ortaya koymaktır. Araştırmada nitel araştırma yöntemlerinden fenomonolojik (olgu bilim) desen kullanılmıştır. Araştırmanın çalışma grubunun belirlenmesinde amaçlı örnekleme yöntemlerinden ölçüt örnekleme kullanılmıştır. Ölçüt örnekleme tekniğinde katılımcıların belirlenmesinde genel olarak araştırma konusu ile ilgisi olan ve bilgi sahibi bireylerden yararlanılmaktadır. Bu çalışmadaki katılımcıların seçiminde uzaktan öğretime tabi tutulmuş üniversite öğrencisi olmaları temel ölçüt olarak belirlenmiştir. Araştırmanın amacı doğrultusunda, araştırma konusuyla ilgili bilgi sahibi olan uzaktan öğretim gören üniversite öğrencilerinin yer aldığı bir çalışma grubu belirlenmiştir. Bu araştırma için belirlenen çalışma grubunda, 2019-2020 eğitim-ögretim yllında uzaktan öğrenim gören Muş Alparslan Üniversitesi 508, Bingöl Üniversitesinde 941 olmak üzere toplam 1449 üniversite öğrencisi yer almıştır. Araştırmada ögrencilerin metafor cümlesini tamamlamaları istenmiştir, çalışmada elde edilen verilerin analizinde "içerik analizi" tekniğinden yararlanılmıştır. Araştırma sonucunda üniversite ögrencileri "Uzaktan öğretim" kavramı ile ilgili 854 farklı metafor üretmiştir. Öğrencilerin ortaya çıkardığı bu metaforlar benzer yönleri göz önüne alınarak kategorileştirilmiştir. Üniversite ögrencilerinin oluşturduğu metaforlar benzerlik durumlarına göre 59 ayrı kod ve olumlu ve olumsu şeklinde 2 ayrı kategori oluşturulmuştur. Araştırma sonuçlarına göre ögrenciler tarafından en fazla "yetersiz olması" kodu altında metafor üretilmiştir $(f=68)$. Araştırmanın bulgularına göre; uzaktan öğretim uygulayıcılarının yeni beceriler ve roller yüklenmesi önerilmektedir.
\end{abstract}

Keywords: Üniversite, Uzaktan öğretim, Metaforik Algı, Üniversite öğrencisi

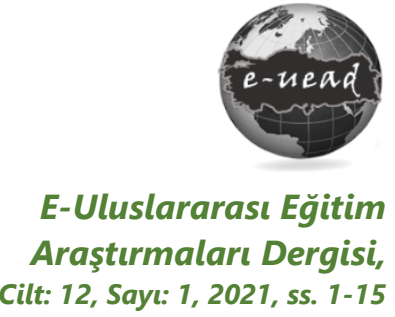

DOI: 10.19160/ijer.786303

Gönderim : 27.08.2020

Revizyon: 25.12.2020 Kabul : 29.01.2021

\section{Önerilen Atıf}

Demirbilek, N. (2021). Üniversite öğrencilerinin uzaktan öğretime ilişkin metaforik algıları. E-Uluslararası Eğitim Araştırmaları Dergisi, Cilt: 12, Sayı 1, 2021, ss. 1-15, DOI: 10.19160/ijer.786303 


\section{Giriş}

Çin'in Wuhan kentinde ortaya çıkan ve tüm dünyayı kısa bir sürede etkisi altına alan covid-19 pandemi sürecinin tüm sektörleri durma noktasına getirdiği gözlenmektedir. Eğitim sektörü de bunlardan biri olmuştur. Türkiye' de 11 Mart'ta ilk vakanın görülmesinden bu yana eğitim sektörü ile ilgili önemli kararlar alınmıştır. 12 Mart'ta alınan karara göre 16 Mart'tan sonra Milli Eğitim Bakanlığına bağlı bütün okullar iki hafta süreyle yüz yüze eğitime ara verildiğini duyurmuştur. Geçen sürede salgının hızının yavaşlamadığı görülünce 23 Mart'tan sonra uzaktan öğretime geçilmiştir. Yükseköğretim kurulu da bu doğrultuda karar almış ve Türkiye'deki bütün üniversitelerde bir anda uzaktan öğretimle ders verilmeye başlanmıştır. Bu hızı değişimin bütün eğitim camiasını uzaktan öğretim konusunda hazırlıksız yakalamış olduğu göze çarpmaktadır. Nitekim dönemin koşulları göz önünde bulundurulduğunda, uzaktan öğretim ile ilgili bütün çalışmalar ciddi önem arz etmektedir. Tüm dünyayı saran covid -19 pandemisi sürecinde bir zorunluluk olan uzaktan öğretim kavramının öğrenciler tarafından net anlaşılamadığı ve zaman zaman zorlanabildikleri görülmektedir. Düşünsel kurgularımızı yapılandıran, yönlendiren ve kontrolünü sağlayan en güçlü bilişsel araçlardan biri olarak aktarılan metaforlar (Saban, 2004) aracılığıyla, anlaşılması güç olan kavramların somutlaştırılması ve daha kolay anlaşılması sağlanabilir. Metaforlar, bireylerin olayları, olguları ve kavramları çeşitli benzetmeler yoluyla nasıl algıladıklarını ve gördüklerini ortaya çıkarmaya katkı sağlayan bir araç olarak düşünülmektedir (Cerit, 2008). Söz konusu kavramın, öğrenciler tarafından açık ve net bir şekilde anlaşııması, öğrencilerin eğitim süreçlerine katkı sağlayabilir. Ayrıca uzaktan öğretimin öğrenciler tarafından nasıl algılandığının eğitimciler tarafından anlaşıımasının önemli olduğu eklenebilir.

Yunanca Metapherin" kelimesinden oluşturulan metafor kelimesinin etimolojisine bakıldığında, meta (uzak) ve pherein (taşımak) sözcüklerinin bir araya gelmesiyle oluştuğu aktarılmaktadır (Levine, 2005). Metaforlar, bireyin kavramsal dünyasının resimleri şeklinde ifade edilebilir (Inam, 2008). Metaforlar iki kavram ya da somut obje arasında benzerlik, ilişki kurma ya da birbirlerinden ayrıştııılmaları görevini üstlenirler (Boozer; Wyld ve Grant, 1992: 20).

Metaforlar, soyut ve karmaşık olan kavramların daha basit bir şekilde açıklanması ve anlaşılması için kullanılabilen zihinsel araçlar olarak değerlendirilir (Saban, 2004, 2008, 2009). Metafor, olgunun veya kavramın kendisi değildir, sembolüdür. Kavramın ya da olgunun kendisi olsaydı, metafora ihtiyaç duyulmazdı. Kavramın ve olgunun anlaşılmasında ve açıklanmasında güçlü bir bakış açısı sunmasına rağmen kavramın ve olgunun kendisinden daha azdır. Bu durumu giderebilmek için birçok metaforun üretilmesi gerekir (Yob, 2003: 134). Ulusal ve uluslararası eğitim literatüründe bu olguyu konu edinen çalışmalar oldukça yaygınlaşmıştır (Demirtaş ve Çoban, 2014).

İnsanların bakış açılarını ortaya çıkarmak ve onların geçmiş tecrübeleri, bugüne dair düşünceleri fikirleri ve geleceğe ait umutları hakkında bilgi sahibi olabilmek için metaforların en doğru araç oldukları vurgulanmaktadır (Levine, 2005). Öğrencilerin, uzaktan öğretim kavramına yönelik algıları kişisel olarak farklılık gösterebilmektedir. Bu algıların olumlu ya da olumsuz olması eğitim sisteminde yer alan bireyleri, öğrenme ortamlarını, öğrenme-öğretme süreçlerini, öğrencilerin eğitim hayatlarını, motivasyonlarını dolaylı doğrudan bütün paydaşları nitelik açısından etkileyebilmektedir. Bu nedenlerle yapılan araştırma, öğrencilerin uzaktan öğretim kavramına yönelik algılarını ve bu algıların nedenlerini ortaya çıkarmada önemli bir çalışma olarak karşımıza çıkmaktadır.

\section{Uzaktan Öğretim}

Tarihte ilk kez mektupla yazılı olarak başlayan Uzaktan öğretim süreci, radyonun icat edilmesi ile işitsel ve ardından televizyonun icadı ile de görsel olarak gelişimini devam ettirmiştir (Moore ve Kearsley, 2005; Simonson, Smaldino, Albright ve Zvacek, 2012). Uzaktan öğretim, her türlü (kablolu, kablosuz ve posta) haberleşmeyi sağlayan kanallar üzerinden; her türlü (internet, 
intranet, video, telefon, televizyon, bilgisayar, radyo, mektup vb.) araçlarla sunulan; öğrenci ile öğretmenin birbirlerinden fiziksel olarak ayrı ortamlarda olmalarına rağmen eş zamanlı ve eş zamansız bir araya gelerek öğrenme ve öğretmeyi kısmen ya da tamamen gerçekleştirdikleri öğretim faaliyetlerinin bütünüdür (Toprakçı, 2008). Ancak uzaktan öğretimin niteliğindeki en büyük değişimi ve gelişimi internetin yaygınlaşmasıyla birlikte web tabanlı eğitim teknolojileri ile olmuştur (Parsad ve Lewis, 2008; İşman, 2011; Simonson ve diğerleri, 2012). Uzaktan öğretim özellikle salgın döneminde, eğitim kurumlarının zorunlu bir parçası haline gelmiştir.

Geleceğin eğitim yöntemi olarak tanımlayabileceğimiz (Duffy ve Kirkley, 2004; Ciabocchi, Ginsberg ve Picciano, 2016). Uzaktan öğretim yerine uzaktan eğitim, online eğitim, online öğretim, çevrimiçi eğitim, çevrimiçi öğretim, dijital öğrenme, e-öğrenme, web tabanlı eğitim, bilgisayar tabanlı eğitim, bilgisayar destekli öğretim, uzaktan öğrenim, uzaktan öğrenme ve bazen de açık öğretim gibi farklı kavramların kullanıldığı gözlenmektedir (Anderson, 2008; Özer, Günlük ve Özcan, 2019). Bu çalışmada özellikle "uzaktan öğretim" kavramının kullanılması Toprakçı'nın (2021) altını çizdiği şu tespitte gizlidir:

"Okullarda yüzyüze işlenen bütün derslerde yapılmaya çalışlan maddi ve manevi değerlerimizin harmanlanarak (eğitimselleştirilerek) öğretimcikler şeklinde çocuklara verilmesi ya da onların bunu almasını sağlamaktır. Uzaktan öğretimde de bu gerçekleştirilebildiği oranda (ki yüzyüze öğretime göre bunun gerçekleştirilmesi çok zordur) o öğretime de 'uzaktan eğitim' denilebilir.

Uzaktan öğretim, öğrencilerin farklı zaman ve mekânlarda eğitim süreçlerini sürdürebilmeleri için kurulan bir alt yapıdır (Hakkari, 2018). Başka bir tanıma göre ise; pedagojik araçların kullanıldığı, internet ve web teknolojileri ile etkinleşen, bunun yanında anlamlı faaliyet ve etkileşimler ile bilgi ve öğrenmenin kolaylaştırıldığı açık ve harmanlanmış öğrenme çevresi olarak tanımlanmıştır (Dabbagh ve Bannan-Ritland, 2005). Uzaktan öğretim, geleneksel eğitimöğretim süreçlerinin çeşitli sınırlııklar nedeniyle ortaya çıkan, yüz yüze eğitim uygulamalarının mümkün olmadığı durumlarda, belirli merkezlerden yürütülen, daha çok kişinin kendi kendisine öğrenmesini hedefleyen, eğitim içeriklerinin özel araçlarla öğrenenlere özel olarak hazırlandığı ve farklı teknolojik araçların kullanıldığı bir eğitim yöntemi olarak da tanımlanmaktadır (Banar ve Fırat, 2015). Uzaktan öğretim yalın anlamılla öğreten ve öğrenenin fiziksel olarak bir arada bulunmadığı bir eğitim biçimidir. Kısacası; zaman ve mekâna bağımlı kalmadan sürdürülen eğitim biçimi olarak özetlenebilir.

Metafor tekniği, yapılan çalışmalarda az kelime kullanılarak anlatılmak istenenin aslında ne olduğunu belirleyen, soyut kavramları somuta çevirmede kolaylık sağlayan bir tekniktir. Bu araştırmada kullanılan metafor tekniği ile öğrencilerin uzaktan öğretim kavramını nasıl algıladıkları, soyuttan somuta dönüştürebilmesi temel alınarak, öğrencilerin uzaktan öğretim kavramını nasıl kavramsallaştırdığı ve neye benzettikleri belirlenmeye çalışılmıştır. Bu nedenle, bu çalışmanın uzaktan öğretim kavramının üniversite öğrencileri tarafından nasıl anlaşıldığı ve içinin nasıl doldurulduğu ile ilgili önemli bulgular ortaya çıkaracağı düşünülmüştür. Ayrıca öğrencilerin uzaktan öğretimden ne anladıkları, onların beklentilerinin neler olduğuna ilişkin görüşlerinin belirlenmesi açısından da oldukça önemlidir. Bu çalışmanın sonuçlarının uzaktan öğretimle ilgili yeni yöntemlerin geliştirilmesine yönelik çalışmalara da katkı sağlayacağı öngörülmektedir.

Literatürde uzaktan öğretim çalışmaları irdelendiğinde, üniversite öğrencilerinin bahsi geçen kavrama yönelik algılarının incelendiği bir araştırmaya rastlanmamıştır. Bu çerçevede araştırmanın amacı, üniversite öğrencilerinin uzaktan öğretim kavramına ilişkin metaforik algılarının incelenmesi olarak belirlenmiştir. bu amaç doğrultusunda araştırma problemi, "Üniversite öğrencilerinin uzaktan öğretime ilişkin metaforik algıları nasıldır?" şeklinde oluşturulmuştur. 


\section{YÖNTEM}

\section{Araştırma modeli:}

Araştırmada, üniversite öğrencilerinin görüşleri doğrultusunda uzaktan öğretim kavramına yüklenen anlamlar derinlemesine incelendiği için nitel araştırma desenlerinden olgu bilim (fenomenoloji) deseni kullanılmıştır. Farkında olduğumuz fakat derinlemesine ve nedenleri ile belirlemek istediğimiz olguların aydınlatılmasında Olgu bilim deseni kullanılmaktadır (Yıldırım ve Şimşek, 2013). Fenomenoloji; daha çok insanın iç dünyasını ve onların bilinç yapılarını anlamaya çalışan bir araştırma desenidir (Mayring, Gümüş ve Durgun, 2011). Olgu bilim ile bize çok yabancı gelmeyen ancak kesinliği hakkında da bir bilgi sahibi olmadığımız olguları, derinlemesine inceleme fırsatı bulur ve zengin söylemlerle yorumlamada bulunma olanağı sağlarız (Yaman, Mermer ve Mutlugil, 2009; Sönmez ve Alacapınar, 2011: 81). Bu bağlamda bireylerin bir olguyu nasıl algıladıkları, açıkladıkları, hatırladıkları ve bu olguyu insanlara aktarmak için nasıl bir dil kullandıkları araştıııı (Patton, 2014). Ayrıca karmaşık kavram, olay ve olguların derinlemesine araştırılmasında etkili bir yöntem olan metafor analizi önemli bir nitel araştırma yöntemi olarak görülmektedir (Güneş ve Fırat, 2016: 125).

\section{Çalışma Grubu:}

Çalışma grubunun belirlenmesinde amaçlı örnekleme yöntemlerinden ölçüt örnekleme tekniği kullanılmıştır. Bu teknik ile katılımcıların belirlenmesinde genel olarak araştırma konusu ile ilgisi olan ve bilgi sahibi bireylerden yararlanılmaktadır (Yıldırım ve şimşek, 2013). Bu çalışmadaki katıımcıların seçiminde uzaktan öğretime tabi tutulmuş üniversite öğrencisi olmaları temel ölçüt olarak belirlenmiştir. Araştırmanın amacı doğrultusunda, araştırma konusuyla ilgili bilgi sahibi olan Uzaktan öğretim gören üniversite öğrencilerinin yer aldığı bir çalışma grubu belirlenmiştir. Bu araştırma için belirlenen çalışma grubunda, 2019-2020 eğitim-öğretim yılında uzaktan öğrenim gören Muş Alparslan Üniversitesi 569, Bingöl Üniversitesinde 1061 olmak üzere toplam 1630 üniversite öğrencisine ulaşılmıştır. Fakat hatalı metafor oluşturan ya da metafor oluşturamayan 181 form elenmiş, sonuç olarak 1449 kişiden oluşmuştur.

Tablo 1
Ögrencilerin oluşturduğu çalışma grubu

\begin{tabular}{|c|c|c|c|}
\hline Değişkenler & Kategori & $\mathbf{N}$ & $\%$ \\
\hline \multirow{2}{*}{ Cinsiyet } & Kadın & 899 & 62,04 \\
\hline & Erkek & 550 & 37,95 \\
\hline \multirow{5}{*}{ Sınıf Düzeyi } & 1.Sinif & 481 & 33,19 \\
\hline & 2.Sinıf & 411 & 28,36 \\
\hline & 3.Sinıf & 246 & 16,97 \\
\hline & 4.Sınıf & 270 & 18,63 \\
\hline & 5. Sınıf ve üstü & 41 & 2,82 \\
\hline \multirow{4}{*}{ Yaşadığı Yer } & Köy & 280 & 19,32 \\
\hline & İlçe/Kasaba & 289 & 19,94 \\
\hline & Şehir & 478 & 32,98 \\
\hline & Büyükşehir & 402 & 27,74 \\
\hline \multicolumn{2}{|c|}{ Toplam Öğrenci Sayısı } & 1449 & \\
\hline
\end{tabular}

\section{Verilerin Toplanması:}

Üniversite öğrencilerinin uzaktan öğretim kavramına ilişkin algılarına metafor yoluyla ulaşmayı amaçlayan bu araştırmada veri toplamak için online ortamda iki bölümden oluşan bir adet form oluşturulmuştur. Birinci bölümde demografik özelliklerin sorulduğu kişsisel bilgi formu yer almaktadır. İkinci bölümde ise katıımcılardan "Uzaktan öğretim ......... gibidir/benzemektedir, çünkü ......." cümlesini tamamlamaları istenmiştir. Ayrıca bu bölümde bazı kavramların metaforları 
hakkında açıklama yapılarak örnekler verilmiş ve bu doğrultuda katılımcılardan tek bir metafor oluşturarak nedenini belirtmeleri istenmiştir (Kılcan, 2017). Hazırlanan formlar mail, WhatsApp gibi araçlar ile gönderilmiş ayrıca Facebook, İnstagram gibi sosyal medya ortamlarında online olarak paylaşılmıştır. Hazırlanan form 1 ay boyunca erişime açık tutulmuştur. Araştırma da uzaktan öğrenim gören 1630 üniversite öğrencisine ulaşılmış fakat hatalı metafor oluşturan ya da metafor oluşturamayan 181 form elenmiş, sonuç olarak 1449 kişiden oluşmuştur. Ayrıca her bir görüşme formu öğrenciler için K1, K2...şeklinde kodlanmıştır.

\section{Verilerin Analizi:}

Araştırmada elde edilen verilerin analizinde içerik analizi kullanılmıştır. İçerik analizinde toplanan veriler, kodlama ve ayıklama, kategori geliştirme aşaması, geçerlik ve güvenirliği sağlama aşaması ve bulguların yorumlanması olmak üzere dört aşamada analiz edilmektedir (Saban, 2008). Illk aşama olan verileri kodlama ve ayıklama aşamasında üniversite öğrencilerinin metaforları incelenmiştir. "Uzaktan Öğretim" kavramını metafor olarak açıklayamayan, metaforun konusu ile kaynağı arasında ilişki bulunmayan veriler elenmiştir $(f=181)$. Örneğin "Uyumak ama uyuduğunu hissetmemek gibi" "Uzaktan öğretim menfaattir çünkü herkes hazıra konmaya çalışır" cümlesinde olduğu gibi kaynak ve sebep var fakat arasındaki ilişkinin mantıklı açıklaması yapılmamıştır. Uzaktan öğretimi açıklamaya katkısı olmayan verilere "Dağ başında açan güldür, çünkü ait olduğu yerde daha iyi olur." "Şeker gibidir, çünkü masrafı yok." "İmkânsızlık gibidir, çünkü bir daha o şansımız olamayacak." "Liman gibidir her an ateşe verilebilir." cümleleri örnek verilebilir. Ayıklama aşamasının ardından ikinci aşama olarak verileri kavramsal kategorilere ayırma işlemi yapılmıştır.

İkinci aşama olan kategori geliştirme aşamasında, öğrenciler tarafından üretilen metaforlar uzaktan öğretim kavramılla ilgili benzer özellikler çerçevesinde gruplanmış ve ayrı kavramsal kategori oluşturulmuştur. Her metafor imgesi öğrencilerin uzaktan öğretim kavramına ilişkin sahip olduğu algıları bakımından ilişkilendirilmiştir.

Üçüncü aşama olan geçerlik ve güvenirliği sağlama aşamasında; araştırmada belirlenen 59 kod ve 2 kategori altında toplanan metaforların söz konusu kategori içinde yer alıp almadığını belirlemek için daha önce metaforik çalışmalar yapmış olan bir uzmanın görüşüne başvurulmuştur. Bu amaçla oluşturulan 854 metaforu ve 59 kodu içeren bir liste uzman görüşüne sunulmuştur. Hiçbir metaforu dışarıda bırakmayacak şekilde metaforları, kavramsal kategorilere yerleştirmesi istenmiştir. Daha sonra uzmanın yaptığı sınıflama ile araştırmacı tarafından yapılan sınıflama karşılaştırılmıştır. İstenilen düzeyde bir güvenilirlik sağlamak için nitel çalışmalarda uzman ve araştırmacı değerlendirmeleri arasındaki uyumun \%90 ve üzeri olması gerekmektedir (Saban, 2008). Yapılan bu araştırmanın güvenirliği (Güvenirlik= Görüş birliği/Görüş birliği+Görüş ayrılığı x 100) ile hesaplanmıştır (Miles ve Huberman, 1994). Araştırma için yapılmış olan hesaplamalar sonucunda \% 96 oranında bir uzlaşma olduğu sonucuna ulaşılmıştır.

Dördüncü aşama olan yorumlama aşamasında öğrenciler tarafından uzaktan öğretim kavramına yönelik oluşturulan metafor sayıları frekans olarak hesaplanmıştır.

\section{BULGULAR}

\section{Uzaktan öğretim Kavramına İlişkin Oluşturulan Metaforlar}

Bu bölümde araştırmanın amacı doğrultusunda uzaktan öğretim kavramına ilişkin oluşturulmuş olan olumsuz ve olumlu metaforlar ve bu metaforların kategorilerine ilişkin analizler tablolaştırılmıştır. Araştırmacılar tarafından uzaktan öğretim kavramı için üretilen metaforlara yönelik olumsuz kodlar ve öğrenci ifadelerinin yer aldığı örnek metaforlar Tablo 2'de verilmiştir. 
Tablo 2:

Üniversite Öğrencilerinin "Uzaktan öğretim" Kavramına Yönelik Oluşturdukları Olumsuz Metaforlar

\begin{tabular}{|c|c|c|c|c|}
\hline Kategori & Kodlar & Örnek Metafor & $\begin{array}{c}\text { Metafor } \\
\text { Sayısı }\end{array}$ & f \\
\hline \multirow{39}{*}{$\frac{N}{\frac{N}{3}}$} & Yetersiz olması & "Uzaktan öğretim, asgari ücret gibidir, çünkü çok yetersizdir (532K)." & 53 & 68 \\
\hline & Verimsiz olması & "Uzaktan öğretim, kırımış bardağa su doldurmak gibidir, çünkü bilgi aktarımı çok zordur (159K)." & 41 & 64 \\
\hline & $\begin{array}{l}\text { Göstermelik eğitim } \\
\text { olması }\end{array}$ & $\begin{array}{l}\text { "Uzaktan öğretim, her şeyi MIş gibi yapmak gibidir, çünkü hiçbir şey olması gerektiği gibi değildir } \\
\text { (668K)." }\end{array}$ & 23 & 51 \\
\hline & $\begin{array}{l}\text { Sosyal ilişkilerin } \\
\text { olmaması }\end{array}$ & $\begin{array}{l}\text { "Uzaktan öğretim, asosyal bir insana benzer, çünkü uzaktan her şeyden haberdar olup olayların içine } \\
\text { karışmak istememesidir (207K)." }\end{array}$ & 16 & 50 \\
\hline & Adaletsiz olması & $\begin{array}{l}\text { "Uzaktan öğretim, ırkçılık gibidir, çünkü herkesin imkânları ayni olmamasına karşın aynıymış gibi } \\
\text { görülür (709K)." }\end{array}$ & 20 & 46 \\
\hline & Etkisiz olması & "Uzaktan ögretim, rüya gibidir, çünkü gelip geçiyor etkisi yok (212K)." & 29 & 44 \\
\hline & Belirsiz olması & $\begin{array}{l}\text { "Uzaktan öğretim, hazine sandığı gibidir, çünkü içinde olan bilinmiyor olması ile birlikte çokça da } \\
\text { önemlidir (1423K)." }\end{array}$ & 34 & 42 \\
\hline & $\begin{array}{l}\text { Anlaşılmıyor } \\
\text { olması }\end{array}$ & "Uzaktan öğretim, çok kötüdür. Ben yakından anlamıyorum uzaktan nasıl anlayayım (318K)." & 30 & 41 \\
\hline & Aldatıcı olması & $\begin{array}{l}\text { "Uzaktan öğretim, yalancı gebelik gibidir, çünkü bir şey öğrendiğini sanırsın ama aslında hiçbir şey } \\
\text { öğrenmemisssindir (996K)." }\end{array}$ & 23 & 39 \\
\hline & $\begin{array}{l}\text { Psikolojik } \\
\text { sorunlara neden } \\
\text { olması }\end{array}$ & "Uzaktan öğretim, "Çukur" gibidir, çünkü lçinde kaldıkça bunalıp daralıyorsunuz (302K)." & 15 & 38 \\
\hline & $\begin{array}{l}\text { Yüz yüze eğitimin } \\
\text { önemi }\end{array}$ & $\begin{array}{l}\text { "Uzaktan öğretim, hapis gibidir, çünkü sınıf içinde yaşanan etkileşimler ve kazanımlar yüz yüze } \\
\text { eğitim gibi olamaz (5K)." }\end{array}$ & 15 & 35 \\
\hline & $\begin{array}{l}\text { İmkânların kısıtlı } \\
\text { olması }\end{array}$ & "Uzaktan öğretim, internetsiz bilgisayar gibidir çünkü internet olmadan bir ise yaramaz (128K)." & 29 & 31 \\
\hline & Karmaşık olması & "Uzaktan ögretim, labirent gibidir. Hepsi karmakarışıktır (69K)." & 19 & 30 \\
\hline & Pasif olması & $\begin{array}{l}\text { "Uzaktan ögrretim, bir üniversitede okumuyormuş ve aşırı sıkıcı bir şeyle uğraşmak zorunda olmak } \\
\text { gibidir çünkü aktif olarak eylemde bulunamıyoruz (623K)." }\end{array}$ & 17 & 29 \\
\hline & Korkutucu olması & "Uzaktan ögrretim, kâbus gibidir çünkü dersler yüzünden sürekli korku içindeyim (1118K)." & 7 & 28 \\
\hline & Zorunlu olması & $\begin{array}{l}\text { "Uzaktan öğretim, Anayasa kuralları gibidir çünkü zorunlu bir şekilde devam ettirmek gereklidir } \\
\text { (1272K)." }\end{array}$ & 15 & 26 \\
\hline & Sıkıcı olması & $\begin{array}{l}\text { "Uzaktan öğretim, tatil gibidir, çünkü herhangi bir ders islenmemekte, bu da bir zamandan sonra } \\
\text { sıkıcı olup okulu unutmamıza neden olmaktadır (624K)." }\end{array}$ & 17 & 26 \\
\hline & Zararlı olması & $\begin{array}{l}\text { "Uzaktan öğretim, ayarlanamayan ilaç dozu gibidir, çünkü dozunu ayarlayamazsan ya etkisiz olur ya } \\
\text { da zehirlenirsin (651K)." }\end{array}$ & 19 & 26 \\
\hline & $\begin{array}{l}\text { Kısıtlamaların } \\
\text { olması }\end{array}$ & $\begin{array}{l}\text { "Uzaktan öğretim, kafes gibidir. Araştırma yapabileceğin yeterli kaynak olmaması ve tek bir şeye } \\
\text { mahkûm olmak (1610K)." }\end{array}$ & 8 & 25 \\
\hline & $\begin{array}{l}\text { Motivasyonsuzluğa } \\
\text { neden olması }\end{array}$ & $\begin{array}{l}\text { "Uzaktan öğretim, arkadaşına ders çalışmaya gidip bütün gece halay çekmek gibidir, çünkü bu } \\
\text { süreçte ful ders çalışacağım diye plan yapıp hiçbir şey yapmadım işin kötüsü beni motive edecek } \\
\text { hiçbir şey yok (1566K)." }\end{array}$ & 13 & 25 \\
\hline & $\begin{array}{l}\text { Sıkı takip } \\
\text { gerektiriyor olması }\end{array}$ & "Uzaktan öğretim, bisiklet gibidir, çünkü pedalı çevirmez isen ilerleyemezsin(1107K)." & 17 & 25 \\
\hline & Yıkıcı olması & $\begin{array}{l}\text { "Uzaktan öğretim, deprem gibidir, çünkü eğitim sistemi Uzaktan öğretim yapılmaya devam ederse } \\
\text { çökecektir (663K)." }\end{array}$ & 11 & 22 \\
\hline & Sağlıksız olması & "Uzaktan öğretim, annesiz çocuğa benzemektedir, çünkü çocuk annesiz sağlıklı büyüyemez (1537K). & 12 & 21 \\
\hline & $\begin{array}{l}\text { Öğrenilmiyor } \\
\text { olması }\end{array}$ & $\begin{array}{l}\text { "Uzaktan ögrretim, futbol oynamayı öğrenmek için tribünden izlemek gibidir, çünkü izliyoruz } \\
\text { görüyoruz ama biz katılamıyor ve öğrenemiyoruz (750K)." }\end{array}$ & 17 & 21 \\
\hline & Faydasız olması & $\begin{array}{l}\text { "Uzaktan öğretim, açık ögretim gibidir, çünkü sadece kaynaklar veriliyor ve sonrada bize sözde sınav } \\
\text { yapılıyor ( } 755 \mathrm{~K}) . "\end{array}$ & 17 & 19 \\
\hline & Kalitesiz olması & "Uzaktan öğretim, talaş gibidir, çünkü tahtanın kalitelisinin yerini tutamaz (1590K)." & 11 & 18 \\
\hline & $\begin{array}{l}\text { Rahatsız edici } \\
\text { olması }\end{array}$ & $\begin{array}{l}\text { "Uzaktan öğretim, Ramazanda suya bakıp içememektir, çünkü okulu görebiliyoruz ama gidemiyoruz } \\
\text { (472K)." }\end{array}$ & 9 & 17 \\
\hline & Yıpratıcı olması & $\begin{array}{l}\text { "Uzaktan öğretim, kara kedi gibidir, çünkü hem hocalarımızın hem arkadaşlarımızın hem de } \\
\text { derslerimizin arasına girdi (1483K)." }\end{array}$ & 9 & 17 \\
\hline & Zor olması & $\begin{array}{l}\text { "Uzaktan öğretim, işkence gibidir, çünkü bu sürece hazır değildik ve birçok yönden eksikliklerimiz } \\
\text { vardı. Tamamen düzenimiz değişmişken ders çalışıp ve } 2 \text { kısa (!) sınav yapmak hiç kolay olmadı } \\
\text { (686K)." }\end{array}$ & 13 & 15 \\
\hline & Soyut olması & $\begin{array}{l}\text { "Uzaktan ögrretim, halüsinasyon gibidir, çünkü uzaktan okula benzese de yanına yaklaşınca okul } \\
\text { olmadığııı anlarsın (1617K)." }\end{array}$ & 11 & 14 \\
\hline & $\begin{array}{l}\text { Ciddiye alınmıyor } \\
\text { olunması }\end{array}$ & $\begin{array}{l}\text { "Uzaktan öğretim, çocuk oyuncağı gibidir, çünkü hiç bir düzen, disiplin yok ögrretim elemanları } \\
\text { istediği zaman ders anlatıyor istemediğinde anlatmıyor, öğrencilerse hiç ciddiye almıyor!(95K)." }\end{array}$ & 8 & 12 \\
\hline & Zevksiz olması & $\begin{array}{l}\text { "Uzaktan ögrretim, gazı kaçmış kola gibidir, çünkü belki hala koladır ama içilecek gibi değildir } \\
\text { (706K)." }\end{array}$ & 6 & 11 \\
\hline & $\begin{array}{l}\text { Sosyal aktivitelerin } \\
\text { olmaması }\end{array}$ & "Uzaktan öğretim, hapis hayatı gibidir, çünkü aktivite sıfır, bilgi sıfır, uğraş sıfır (305K)." & 4 & 10 \\
\hline & Güvensiz olması & $\begin{array}{l}\text { "Uzaktan öğretim, penceresiz ev gibidir, çünkü nerden ne tehlike geleceğini göremezsin ve } \\
\text { güvenilirliği yoktur(1004K)." }\end{array}$ & 8 & 9 \\
\hline & Uçucu olması & $\begin{array}{l}\text { "Uzaktan öğretim, havadaki toz gibidir, çünkü tozun havada tutumu ne ise uzaktan öğretimde odur } \\
\text { (1169K)." }\end{array}$ & 3 & 8 \\
\hline & $\begin{array}{l}\text { Sonuç odaklı } \\
\text { olması }\end{array}$ & $\begin{array}{l}\text { "Uzaktan ögrretim, anlamadan okunan ve sonunda bir imtihan isteyen bir kitap gibidir, çünkü } \\
\text { okumadan sınava giriyoruz (702K)." }\end{array}$ & 6 & 8 \\
\hline & Yorucu olması & "Uzaktan ögrretim, sakız gibidir, çünkü yapıştı ve gitmiyor (705K)." & 5 & 5 \\
\hline & Kontrolsüz olması & $\begin{array}{l}\text { "Uzaktan öğretim, akademisyenlerin hoşuna gitmeyen bir şey gibidir, çünkü işler planladıkları gibi } \\
\text { gitmemektedir (1250K)." }\end{array}$ & 3 & 5 \\
\hline & Bağımlılık yapması & "Uzaktan öğretim, sigara gibidir, çünkü bırakmak istiyorsun bırakamıyorsun (265K)." & 2 & 2 \\
\hline
\end{tabular}


Tablo 2'de görüldüğü üzere araştırmacılar tarafından uzaktan öğretim kavramı için üretilen metaforlara yönelik 39 kod şekillenmiş ve bunlar "olumsuz" kategorisini biçimlemiştir. Öğrenciler tarafından en fazla "yetersiz olması" kodunda metafor üretilmiştir ( $f=68)$. Daha sonra gelen metafor kodları sırasıyla; "verimsiz olması" ( $f=66)$, "göstermelik eğitim olması" $(F=51)$ kodlarıdır. En az metafor üretilen kodlar ise "yorucu olması" $(f=4)$, "kontrolsüz olması" ( $f=2)$ ve "bağımlılık yapması" ( $f=2$ ) olarak belirlenmiştir.

Bu kodlardan hareketle yürütülen eğitim çalışmalarının öğrenciler üzerindeki etkisinin minimum düzeyde kaldığını söyleyebiliriz. Üniversitelerde yürütülen eğitim faaliyetlerinin öğrenciler tarafından yetersiz, verimsiz ve göstermelik olduğu şeklinde algılandığı göze çarpmaktadır. Araştırmacılar tarafından uzaktan öğretim kavramı için üretilen metaforlara yönelik olumlu kodlar ve öğrenci ifadelerinin yer aldığı örnek metaforlar Tablo 3'de verilmiştir.

Tablo 3: Üniversite Öğrencilerinin "Uzaktan öğretim" Kavramına Yönelik Oluşturdukları Olumlu Metaforlar

\begin{tabular}{|c|c|c|c|c|}
\hline Kategori & Kodlar & Örnek Metafor & $\begin{array}{l}\text { Metafor } \\
\text { Sayısı }\end{array}$ & $\mathbf{f}$ \\
\hline \multirow{20}{*}{$\frac{\underline{\underline{z}}}{\frac{5}{2}}$} & Sürekliliğin olması & $\begin{array}{l}\text { "Uzaktan öğretim, örgün öğretim gibidir, çünkü her şeyi tam anlamıyla } \\
\text { anlayabiliyoruz (682K)." }\end{array}$ & 11 & 54 \\
\hline & Eğlenceli olması & $\begin{array}{l}\text { "Uzaktan ögretim, telefonda oyun oynamaya benzemektedir, çünkü çok } \\
\text { eğlencelidir (690K)." }\end{array}$ & 23 & 47 \\
\hline & Etkili olması & $\begin{array}{l}\text { "Uzaktan öğretim, özel ders gibidir, çünkü hocamız bize özel anlatıyormuş gibi } \\
\text { ve daha dikkat dağıtan olaylardan uzak (157K)." }\end{array}$ & 29 & 44 \\
\hline & $\begin{array}{l}\text { Zaman ve mekân } \\
\text { özgürlüğünün } \\
\text { olması }\end{array}$ & $\begin{array}{l}\text { "Uzaktan öğretim, teknoloji gibidir, çünkü her zaman ulaşılabilir ve yakınında } \\
\text { (832K)." }\end{array}$ & 17 & 41 \\
\hline & Güvenli olması & $\begin{array}{l}\text { "Uzaktan öğretim, güvenli alan gibidir, çünkü böyle bir dönemde öğrencilerin } \\
\text { kaygısını azaltmaya yardımcı olur (617K)." }\end{array}$ & 15 & 38 \\
\hline & $\begin{array}{l}\text { Araştırmaya sevk } \\
\text { etmesi }\end{array}$ & $\begin{array}{l}\text { "Uzaktan öğretim, at gibidir, çünkü hep daha fazla çabalamayı ve en tepeye } \\
\text { çıkma çabasıdır, çünkü hırs ve rekabetten geçer (830K)." }\end{array}$ & 17 & 33 \\
\hline & Rahat olması & $\begin{array}{l}\text { "Uzaktan ögretim, ev gibidir, çünkü insanın evinde rahat olması gibi bizim de } \\
\text { dersleri rahatlıkla vermemiz (1254K)." }\end{array}$ & 21 & 30 \\
\hline & Koruyucu olması & "Uzaktan öğretim, can kurtarır, çünkü zor zamanda insan dostudur (637K)." & 14 & 20 \\
\hline & $\begin{array}{l}\text { Geçici bir alternatif } \\
\text { olması }\end{array}$ & $\begin{array}{l}\text { "Uzaktan öğretim, powerbank gibidir, çünkü eğitimden yoksun bırakmıyor } \\
(146 K) . "\end{array}$ & 15 & 17 \\
\hline & Sağlıklı olması & $\begin{array}{l}\text { "Uzaktan Öğretim, ilaç gibidir, çünkü cehalet denen hasatlıktan kurtarır } \\
\text { (1075K)." }\end{array}$ & 10 & 16 \\
\hline & İhtiyaç olması & $\begin{array}{l}\text { "Uzaktan öğretim, güneş gözlügü gibidir, çünkü ihtiyaçtır zorunluluk değildir } \\
\text { (1302K)." }\end{array}$ & 8 & 15 \\
\hline & İlgi istiyor olması & $\begin{array}{l}\text { "Uzaktan öğretim, nazik bir çiçek gibidir, çünkü bakmazsan kurur ve derslerin } \\
\text { düşer (172K)." }\end{array}$ & 8 & 11 \\
\hline & Modern olması & $\begin{array}{l}\text { " Uzaktan öğretim, dijital okul gibidir, çünkü çocukları uzakta da kontrol } \\
\text { edebiliyor ( } 728 K) \text {. }\end{array}$ & 9 & 11 \\
\hline & Kolay olması & "Uzaktan öğretim, kek gibidir, çünkü kolay, sağlıklı ve lezzetlidir (671K). " & 8 & 10 \\
\hline & Ayırt edici olması & $\begin{array}{l}\text { "Uzaktan öğretim, doğal seçilim gibidir, çünkü doğal seçilimde güçlü olan, } \\
\text { uyum sağlayan hayatta kalır (1053K)." }\end{array}$ & 9 & 10 \\
\hline & Yeni olması & $\begin{array}{l}\text { "Uzaktan öğretim, yeni doğmuş bir bebek gibidir, çünkü keşfedilmeyi bekliyor } \\
(416 K) . "\end{array}$ & 7 & 9 \\
\hline & Her yerde eğitim & $\begin{array}{l}\text { "Uzaktan öğretim, bilgisayara yüklenmiş seyyar okul gibidir, çünkü } \\
\text { bilgisayarım nerdeyse Uzaktan öğretim ordadır }(171 \mathrm{~K}) . "\end{array}$ & 6 & 7 \\
\hline & $\begin{array}{l}\text { Uzağı yakın ediyor } \\
\text { olması }\end{array}$ & "Uzaktan öğretim, dürbün gibidir, çünkü uzağı yakınlaştırıyor (742K). " & 6 & 6 \\
\hline & Tamamlayıcı olması & $\begin{array}{l}\text { "Uzaktan öğretim, sözcük gibidir, çünkü cümlenin oluşumunu tamamlar } \\
\text { (598K)." }\end{array}$ & 4 & 4 \\
\hline & Maliyetin az olması & "Uzaktan öğretim, şeker gibidir, çünkü masrafı yok (158K)." & 2 & 2 \\
\hline
\end{tabular}

Tablo 3'de görüldüğü üzere araştırmacılar tarafından uzaktan öğretim kavramı için üretilen olumlu metaforlara yönelik 20 kod oluşturulmuştur. Öğrenciler tarafından en fazla "sürekliliğin olması" koduyla metafor üretilmiştir $(f=54)$. Daha sonra gelen metafor kodları sırasıyla; "eğlenceli olması" ( $f=66)$, "etkili olması" ( $F=51)$ kodlarıdır. En az metafor üretilen kodlar ise "uzağı yakın ediyor olması" ( $f=6)$ "tamamlayıcı olması" ( $f=4)$ ve "maliyetin az olması" $(f=2)$ olarak belirlenmiştir. Bu kodlardan hareketle öğrencilerin, eğitimin aksamamış ve devam edilmiş olmasını olumlu bir durum olarak algıladıkları görülmektedir. Devamsızlık gibi bir sorunun 
olmamasını eğlenceli olarak gördükleri ve zaman tasarrufundan dolayı daha etkili olacağına ilişkin görüş belirttikleri görülmektedir. Ayrıca, eğitimlerini evden yapabiliyor olmalarını, sağııkı bir yöntem ve eğitim maliyetlerini azaltmış olması durumlarından dolayı memnuniyet verici olarak karşıladıklarını ifade etmişlerdir.

Olumlu bakış ile olumsuz bakışı karşılaştırdığımızda; olumsuz kodlar 39 tane iken olumlu kodların 20 tane olduğu görülmektedir. Toplam metafor sayısı bakımından irdelediğimizde, olumsuz metafor sayısı 764 iken olumlu metafor sayısı 425 olarak bulgulanmıştır. Bu bulgulardan hareketle olumsuz algılar, olumlu algıların neredeyse iki katı kadar olduğu saptanmıştır. Olumsuz bakışın bu kadar fazla olması dikkat edilmesi gereken bir sonuç olarak karşımıza çıkmaktadır. Çünkü eğitimin uzaktan yapılması bir tercih değil, zorunluluk olduğu neredeyse herkes tarafından bilinmekte ve kabul edilmektedir. Bu mücbir sebeplere (sağlık koşulları) rağmen acil bir şekilde uzaktan yürütmeye çalıştığımız eğitimin bu düzeyde olumsuz algılanmasının sebebi olarak yürütülen eğitim faaliyetlerinin "mış gibi" yapılması olduğu söylenebilir. Ayrıca, bütün eğitim paydaşlarının uzaktan eğitim platformuna yabancı oldukları ve acemi oldukları başka bir sebep olarak eklenebilir.

\section{SONUÇ, TARTIŞMA VE ÖNERILER}

$\mathrm{Bu}$ araştırmada çalışma grubu olarak seçilen üniversite öğrencilerinin "uzaktan öğretim" kavramına ilişkin metaforların ortaya çıkarılması ve bu metaforların belli kodlar ve kategoriler altında toplanması amaçlanmıştır. Bu çalışmanın sonuçları, birkaç önemli noktaya vurgu yapmaktadır. Üniversite öğrencilerinin "uzaktan öğretim " kavramına ilişkin çok fazla metafor üretmeleri "uzaktan öğretim" kavramının, kapsamının kodlarda da görüldüğü üzere geniş, karışık ve soyut olmasından kaynaklanmaktadır. Bu verilerden hareketle üniversite öğrencilerinin "uzaktan öğretim" kavramına ilişkin birçok metafor üretmeleri sağlanmış ve uygulamadaki eksiklikleri saptanmıştır.

Araştırmacılar tarafından uzaktan öğretim kavramı için üretilen metaforlara yönelik oluşturulan kodlar frekans bakımından sırasıyla; yetersiz, verimsiz, süreklilik, göstermelik eğitim, sosyal ilişkilerin olmaması, eğlenceli, adaletsiz, etkili, etkisiz, belirsiz, zaman mekân özgürlüğü, anlaşılmıyor, aldatıcı, güvenli, psikolojik sorunlar, yüz yüze eğitimin önemi, araştırmaya sevk etmesi, imkânlar kısıtll, karmaşık, rahat, pasif, korkutucu, zorunlu, sıkıcı, zararlı, kısıtlama, motivasyonsuzluk, sıkı takip, yıkıcı, sağlıksız, öğrenilmiyor, koruyucu, faydasız, kalitesiz, rahatsız edici, yıpratıcı, sağlıklı, zor, ihtiyaç, ilgi istiyor, soyut, ciddiye alınmıyor olunması, zevksiz, modern, kolay, geçici bir çözüm, ayırt edici, sosyal aktivitelerin olmaması, yeni, güvensiz, uçucu, sonuç odaklı, alternatif, her yerde eğitim, uzağı yakın ediyor, yorucu, kontrolsüz, tamamlayıcı, maliyetin az, bağımlıık yapması gibi toplam 59 kodun yer aldığı görülmüştür.

Araştırma da ortaya çıkan kodlar tek tek ele alındığında olumlu ve olumsuz kategoriler olarak ayrıştıkları görülmektedir. Olumsuz olan kategorinin; yetersiz, verimsiz, göstermelik eğitim, sosyal ilişkilerin olmaması, adaletsiz, etkisiz, belirsiz, anlaşılmıyor, aldatıcl, psikolojik sorunlar, yüz yüze eğitimin önemi, imkânlar kısıtlı, karmaşık, pasif, korkutucu, zorunlu, sıkıcı, zararlı, kısıtlama, motivasyonsuzluk, sıkı takip, yıkıcı, sağlıksız, öğrenilmiyor, faydasız, kalitesiz, rahatsız edici, yıpratıcı, zor, soyut, ciddiye alınmıyor olunması, zevksiz, sosyal aktivitelerin olmaması, güvensiz, uçucu, sonuç odaklı, yorucu, kontrolsüz, bağımlılık yapması gibi 39 koddan oluştuğu; olumlu olan kategorinin ise süreklilik, eğlenceli, etkili, zaman mekân özgürlügü, güvenli, araştırmaya sevk etmesi, rahat, koruyucu, sağlıklı, ihtiyaç, ilgi istiyor, modern, kolay, ayırt edici, yeni, geçici alternatif, her yerde eğitim, uzağı yakın ediyor, tamamlayıcı, maliyeti az gibi 20 koddan oluştuğu görülmüştür.

Olumsuz olan kategorideki kodlar incelendiğinde, eğitim süreçlerini ciddi bir biçimde aksatan faktörler olduğunu söyleyebiliriz. Olumsuz olarak değerlendirilen kodların uzaktan öğretim kavramının tanımından ziyade uygulamadaki hatalara vurgu yaptığı görülmektedir. Çalışmada ortaya çıkan sonuçlara göre yapılan uzaktan öğretimin eksikleri bulunduğundan dolayı yetersiz olarak algılanmış ve bu nedenle en fazla dile getirilen kod olarak ortaya çıkmıştır. Bu eksikliklerin eğitim süreçlerinin verimsiz ve etkisiz olmasına sebep olduğu ifade edilmiştir. 
Alan yazında araştırmanın bulgularını destekleyen çalışmalar yer almaktadır. Uzaktan öğretimin etkisiz ve yetersiz olduğunu düşünen öğretmenlerin salgın sürecinde mesleki doyumlarının azaldığı tespit edilmiştir (Bakioğlu ve Çevik, 2020; Kavuk ve Demirtaş, 2021). Bu süreçte öğretmenler öğretim sürecinin kontrol edilmesi ve denetlenmesi konularında kendilerini yetersiz hissetmektedir (Kantos, 2020; Kavuk ve Demirtaş, 2021). Ayrıca bu eksikliklere ek olarak belirsiz, anlaşılmıyor, imkânlar kısıtlı, karmaşık, öğrenilmiyor, faydasız, uçucu gibi kodlarında eğitim süreçlerindeki yetersizliğin artmasına sebep olduğu görülmüştür. Bu verilerden hareketle üniversite öğrencilerinin başta kısıtı olan imkânlarının iyileştirilmesi, sonra da diğer eksikliklerinin giderilmesi konusunda yetkili olan kişilerin aracı olması gerektiği düşünülmektedir.

Üniversite öğrencilerinin, sosyalleşme ve iletişim konularında şikâyetçi oldukları saptanmıştır. Pandemi sürecinde zorunlu olarak ortaya çıkan sosyal mesafe kuralı kurumlar arasında en fazla eğitim kurumlarını olumsuz olarak etkilediği düşünülmektedir, çünkü başta Bloom (1956) olmak üzere pek çok araştırmacı tarafından kabul gören sosyal öğrenmeyi engellemiştir. Nitekim araştırma sonuçları da sosyal ilişkilerin olmaması ve sosyal aktivitelerin olmaması kodları ile sosyal öğrenmenin tehdit altında olduğunu tespit etmiş̧tir. Ayrıca bu durum sosyal ilişkilerin olmaması kodu altında; uzay boşluğu (1), yokluk (1), boşluk (1), tek odalı ev (1), demir parmaklık (1), duvar (1), bir ada da yalnız kalmış bir insan (1), duygusuz insan (1), zulüm (1), asosyal (2), açık cezaevi (2), teknolojik esaret (3), cehennem (3), ruhsuz bir beden (4), hapis (10), kafes (17) gibi metaforlar aracılığıyla ifade edilmiştir. Bu çerçevede sosyal medya ağlarının ders içi kullanımını yaygınlaştırarak üniversite öğrencilerinin daha fazla sosyalleşmeleri sağlanabilir. Uzaktan öğretim öğretmenlerin meslektaşları ve öğrencileri ile olan iletişimini sınırlandırmaktadır (Djalilova, 2020). Uzaktan canlı ders yapan öğretmenlerin bu süreçte yeteri kadar rehberlik yapamadıkları, öğrencilerle etkileşimin yeterli olmadığı (Başaran, Doğan, Karaoğlu ve Şahin, 2020), eş zamanlı derslere katılım düzeyinin düşük olduğu, öğrencilerle iletişim sorunları yaşandığı ve öğrencilere yeterince sosyal destek sağlanamadığı tespit edilmiştir (Genç, 2020).

Araştırma sonuçlarına göre verilen eğitimin ciddi bir şekilde yapılmadığı aksine göstermelik yapıldığı ifade edilmiştir. Bu durum göstermelik eğitim kodu altında; geleneksel eğitim (1), ha okudun ha okumadın (1), sürekli ahkâm kesen bilge (1), göle maya çalmak (1), su içmek ama içtiğini hissetmemek (1), uyumak ama uyuduğunu hissetmemek (1), vicdan rahatlatmak (1), dijital ortamdaki yemek (1), boş gözler (1), üstün körü (1), israf (1), bayat ekmek (1), sözde sınav (1), fast food (2), boşluk (2), her şeyi mış gibi yapmak (3), bomboş (3), formalite (3), boş uğraş (3), boş (3), ölü eğitim, saçmalık (4), yok (11) gibi metaforlar aracılığıyla yansıtıldığı görülmüştür. Uzaktan öğretimin kalitesini ve başarısını etkileyen faktörlerin başında uzaktan öğretimde görev alan öğretim elemanları gelmektedir (Nielsen, 1997: 286). Eğitim-öğretim kurumunun uzaktan öğretim konusunda yeterli ve etkili olabilmesinin ön koşullarından birisi iş görenlerin uzaktan öğretim faaliyetlerini yürütmeye istekli olmasıdır (Canpolat ve Canpolat, 2020). Eğiticilerin uzaktan öğretim teknolojilerini kullanma konusunda yetersiz, tecrübesiz olması ve bu nedenle uzaktan öğretime olumsuz bakması, öğrencilere de olumsuz olarak yansımaktadır (Nenko, Kybalna ve Snisarenko, 2020; Genç, 2020). Ayrıca eğiticilerin uzaktan öğretim sürecinde, dersler için yeterli ve etkili öğretim materyali hazırlama ve sunmada sorunlar yaşamaktadır (Genç ve Gümrükçüoğlu, 2020). Uzaktan eğitim sürecinde kullanılabilecek ders materyallerin sınırlı olması öğrencilerin öğrenme sürecini de olumsuz etkilemektedir. Bu nedenle nitelikli bir uzaktan öğretim için dijital ders içeriklerinin sayısı ve niteliği artırılarak, uzaktan öğretim sistemleri zenginleştirilmelidir (Başaran ve diğerleri, 2020). Bu bağlamda başta akademisyenler olmak üzere eğitimin tüm paydaşlarının eğitim süreçlerini daha ciddi bir şekilde yürütebilmeleri için seminerler verilmesi ayrıca maddi teşvik araçları kullanılması önerilmektedir.

Araştırma sonuçlarına göre eğitim süreçlerinin değerlendirme boyutunun adaletli olmadığı tespit edilmiştir. Adaletsiz olması kodu altında; hukuk (1), eziyet (1), deli dumrul köprüsü (1), ırkçlık (1), haksızlık (1), ön yargılı olmak (1), şanssızlık (1), zorba (1), hak yeme (1), oltaya takılan balık (1), saçmalık (1), eşitsizlik (2), torpil (2), ayrımcılık (2), sürekli ödev (3), kopya (3), kopya çekerek okulu bitirme (4), hırsız (5), yanlış tartan terazi (6), adaletsiz (8) gibi metaforlar ile bu 
durum dile getirilmiştir. Ayrıca güvensiz, sonuç odaklı, kontrolsüz gibi kodların, adaletsiz olma durumunu desteklediği görülmüştür. Bu veriler ışığında eğitim süreçlerinde değerlendirme boyutunun daha şeffaf yürütülmesi ve objektif kriterlerin olması gerektiği düşünülmektedir.

Pandemi sürecinin psikolojik sorunlara neden olduğu gözlenmektedir. Bu durumu kaygı (1), sokağa atılmış üvey evlat (1), feci (1), kapalı alan fobisi (1), tımarhaneye kapatılmak (1), paslı demir (1), virüs (2), eziyet (2), çukur (2), kafes (3), cezaevi (3), cehennem (4), yalnızlık (4), stres (6), hapis (6) gibi metaforlarla anlatıldı̆ı görülmüştür. Bunun yanında korkutucu, sıkıcl, zararlı, kısıtlama, motivasyonsuzluk, yıkıcı, sağlıksız, rahatsız edici, yıpratıcı, zevksiz, yorucu, bağımlılk yapması gibi kodlar ise psikolojik sorunların ne kadar yoğun yaşandığının göstergeleri olarak yorumlanabilir. Salgın nedeniyle uzunca bir süre evlerinde kalan ve kendilerine virüs bulaşacağı endişesi taşıyan öğrencilerin stres düzeyi yükselmiştir (Al Lily, Ismail, Abunasserand Alqahtani, 2020). Yürütülen uzaktan öğretim sürecinin acil ve mecburi olduğunun bilinmesi bile öğrencileri hatta tüm paydaşları kaygıya sürüklediği gözlenmektedir. Bu bağlamda üniversite öğrencilerine yönelik psikolojik desteklerin sunulması ve psikolojik çalışmaların daha fazla yapılması önerilebilir.

Üniversite öğrencilerinin pandemi süreciyle birlikte başlayan uzaktan öğretim yerine yüz yüze eğitimi tercih ettikleri gözlenmiştir. Bu durumu yüz yüze eğitimin önemi kodu altında; cahillik (1), aileden uzaklaşmak (1), sıla (1), bir annenin yavrusunu askerde beklemesi (1), içimizde yanan kor ateş (1), yuvadan kaçan kuş (1), farkındalık (1), sevdiğin birinden uzak kalmak (1), sütten kesilmiş çocuk (1), yüz yüze eğitim (2), hasret (2), umut (3), özlemek (4), gurbet (15) gibi metaforlar aracılıyla ifade ettikleri görülmüştür. Ayrıca aldatıcı, geçici bir çözüm, zorunlu, zor, kalitesiz, gibi kodlar ile yüz yüze eğitimi tercih ettikleri ortaya çıkarılmıştır. Nitekim alanyazın incelendiğinde, zorunlu durumlarda imkân varsa, tamamen uzaktan öğretim yerine, örgün eğitimle uzaktan öğretimin beraber yürütüldüğü hibrid/harmanlanmış eğitim sisteminin kullanılması önerilmektedir (Kantos, 2020). Ayrıca, uzaktan öğretim adı altında yürütülen faaliyetlerin aslında uzaktan öğretim faaliyeti olduğu ve bu faaliyetlerin örgün eğitimin yerini tutamayacağı aktarılmaktadır (Yıldıım, 2020; Yılmaz, 2020).

Olumlu olarak değerlendirilen kodlara baktığımızda uzaktan öğretim süreçlerinin gelecekte daha fazla kullanılacağını öngörebiliriz. Özellikle zaman mekân özgürlüğü kodu altında bulunan metaforların bu duruma ışık tuttuğu gözlenmektedir. Bu durum zaman mekân özgürlüğü kodu altında; özgür kuş (1), çok iyi (1), zaman tasarrufu sağlayan uygulama (1), uçsuz bucaksız deniz (1), avantaj (1), uçsuz bucaksız bahar bahçesi (1), küreselleşme (2), iyi (2), tatil (2), nefes almak (2), kafesten kurtulmuş kuş (2), teknoloji (3), gelecek (3), kitap (3), kuş (4), fursat (4), özgürlük (8) gibi metaforlar aracılığıyla ifade edilmiştir. Uzaktan öğretim mekân ve zaman sınırlamasını ortadan kaldırarak, internet erişimi olan her yerden gerçekleştirilebilir (Djalilova, 2020). Bu sebeple uzaktan öğretim alt yapısının daha fazla güçlendirilmesi ve geliştirilmesi gerektiği öngörülmektedir.

Pandemi ile birlikte mecburi olan uzaktan öğretimin en büyük etkisi öğrenme ortamlarını, öğretim araçlarını ve hatta öğretmenlerin pedagojik yaklaşımlarını yeniden şekillendirmesine neden olmasıdır. Yani uzaktan öğretimde başta öğretmen olmak üzere eğitim ile ilgili herkesin rolü değişmektedir (Toprakçı ve Ersoy). Çünkü uzaktan öğretim süreçleri, yeni bir öğrenme ortamını zorunlu kılmaktadır. Dünyanın neredeyse her tarafında pek çok eğitim kurumu öğrencilerine uzaktan öğretim sunmaya başlamıştır. Bu uzaktan öğretim uygulayıcılarının yeni beceriler, roller ve hatta öğrenme yöntemleri kullanılması gerektiği görülmektedir. Dolayısıyla, geleneksel yüz yüze eğitim yöntemlerine alışkın olan eğitimcilerin, uzaktan öğretim yöntem ve yaklaşımlarına sahip olmaları gerekmektedir. Bu amaçlar doğrultusunda, aşağıdaki öneriler geliştirilmiştir.

\section{Öneriler}

- Çevrimiçi yöntem ve yaklaşımları kazanabilmeleri için mesleki gelişime ihtiyaçları olan akademik personele seminer çalışmaları hazırlanabilir. 
- Akademisyenlerin bu değişime adapte olabilmeleri için mentörlük programları oluşturulabilir.

- Uzaktan öğretim zorunlu nedenler dışında örgün eğitimi destekleyecek şekilde kullanılmalıdır.

- Akademik personele yönelik dijital eğitim içeriği hazırlama eğitimleri düzenlenebilir.

- Öğrencilerin dijital okuryazarlık becerilerinin artırılabilmesi için, Bilişim Teknolojileri ders sayıları artıılarak, tüm eğitim kademelerinde zorunlu ders kapsamına alınabilir.

- Üniversiteler tarafından salgın sürecinde kaygı ve stres düzeyi yüksek olan öğrencilere yönelik düzenlenen uzaktan rehberlik hizmetlerinin benzeri, akademik ve idari personele de sağlanabilir.

\section{KAYNAKLAR}

Al Lily, A. E., Ismail, A. F., Abunasser, F. M., and Alqahtani, R. H. A. (2020). Distance education as a response to pandemics: Coronavirus and Arab culture. Technology in Society, 101317.

Anderson, T. (Ed.). (2008). The theory and practice of online learning. Athabasca University Press.

Bakioğlu, B. ve Çevik, M. (2020). COVID-19 pandemisi sürecinde fen bilimleri öğretmenlerinin uzaktan eğitime ilişkin görüşleri. Electronic Turkish Studies, 15 (4).

Banar, K., ve Fırat, M. (2015). Bütüncül bir bakıştan açık ve uzaktan eğitim: Türkiye özeli. Yeğitek Uzaktan Eğitim Özel Sayısı, 18-23.

Başaran, M., Doğan, E., Karaoğlu, E. ve Şahin, E. (2020). Korona virüs (Covıd-19) pandemi sürecinin getirisi olan uzaktan eğitimin etkililiği üzerine bir çalışma. Academia Eğitim Araştırmaları Dergisi, 5 (2), 368397.

Bloom, B. S. (1956). Taxonomy of educational objectives. Vol. 1: Cognitive domain. New York: McKay, 20, 24

Boozer, Robert W., David C. Wyld, and James Grant (1991), "Using metaphor to create more effective sales messages," Journal of Consumer Marketing, 8 (2), 59-67.

Canpolat, U. ve Canpolat, N. Z. (2020). Uzaktan eğitim bağlamında e-hazır olma kavramııı irdelenmesi. Açıköğretim Uygulamaları ve Araştırmaları Dergisi, 6 (3), 79-91.

Cerit, Y. (2008). Öğretmen kavramı ile ilgili metaforlara ilişkin öğrenci, öğretmen ve yöneticilerin görüşleri. Journal of Turkish Educational Sciences, 6(4).

Ciabocchi, E., Ginsberg, A. and Picciano, A. (2016). A Study of faculty governance leaders' perceptions of online and blended learning. Online Learning, 20(3), 52-73.

Dabbagh, N. and Bannan-Ritland, B. (2005). Online learning: Concepts, strategies, and application (pp. 68107). Upper Saddle River, NJ: Pearson/Merrill/Prentice Hall.

Demirtaş, H. ve Çoban, D. (2014). Üniversite öğrencilerinin öğretim elemanlarına ilişkin metaforları. Kastamonu Eğitim Dergisi, 22(3), 1279-1300.

Djalilova, K. M. (2020). Advantages and disadvantages of distance learning. Наука и образование сегодня, (7), 70-72.

Duffy, T. M. and Kirkley, J. R. (2004). Learning theory and pedagogy applied in distance learning: The case of Cardean University. Learner-centered theory and practice in distance education: Cases from higher education, 107-141.

Genç, M. F. ve Gümrükçüoğlu, S. (2020). Koronavirüs (Covıd-19) sürecinde ilâhiyat fakültesi öğrencilerinin uzaktan eğitime bakışları. Electronic Turkish Studies, 15 (4).

Genç, S. (2020). Uzaktan eğitim uygulamalarının öğretmen görüşlerine göre incelenmesi. International Journal of Innovative Approaches in Education, 4 (3), 101-107. Doi: 10.29329/ijiape.2020.271.3

Güneş, A. ve Fırat, M. (2016). Açık ve uzaktan öğrenmede metafor analizi araştırmaları. Açık öğretim Uygulamaları ve Araştırmaları Dergisi, 2(3), 115-129.

Hakkari, F. (2018). Meslek yüksekokulu öğrencilerinin nomofobi düzeylerinin belirlenmesi: Kırıkhan MYO örneği. Atlas International Referred Journal on Social Sciences, 4(10), 786-797.

Kavuk, E. ve Demirtaş, H. (2021) COVID-19 Pandemisi Sürecinde Öğretmenlerin Uzaktan Eğitimde Yaşadığı Zorluklar. E-Uluslararası Pedandragoji Dergisi (E-UPAD) 1 (1), 56-73 Erişim: https://www.eijpa.com/index.php/pedandragoji/article/view/20 
Kantos, Z. E. (2020). Sınıf öğretmenlerinin uzaktan eğitim ile ilgili düşünceleri. 8. Uluslararası Bilimsel Araştırmalar Kongresi-Sosyal ve Eğitim Bilimleri, 67.

Kılcan, B. (2017). Metafor ve eğitimde metaforik çalışmalar için bir uygulama rehberi. Pegem Akademi Yayınları.

İnam, Ö. (2008).Televizyon reklamlarında metafor kullanımı. (Yayımlanmamış doktora tezi). Anadolu Üniversitesi Sosyal Bilimler Enstitüsü.

İşman, A. (2008). Uzaktan eğitim. Pegem Akademi Yayınları.

Levine, P. M. (2005). Metaphors and images of classrooms. Kappa Delta Pi Record, 41(4), 172-175.

Mayring, P., Gümüş, A. ve Durgun, S. M. (2011). Nitel sosyal araştırmaya giriş: nitel düşünce için bir rehber. Bilgesu Yayıncılık.

Miles, M. B. and Huberman, A. M. (1994). Qualitative data analysis: An expanded sourcebook. Sage.

Moore, M. G. and Kearsley, G. (2005). Distance education: A systems view (2nd ed.). Belmont, CA: Wadsworth.

Nenko, Y., Kybalna, N. and Snisarenko, Y. (2020). The COVID-19 Distance Learning: Insight from Ukrainian students. Revista Brasileira de Educação do Campo, 5, e8925-e8925.

Nielsen, H.D. (1997) Quality assessment and quality assurance in distance teacher education. Distance Education, 18(2), 284-317.

Özer, G., Günlük, M. ve Özcan, M. (2019). Muhasebe akademisyenlerinin muhasebe eğitiminde uzaktan eğitim uygulamaları kullanımına yönelik algılarının teknoloji kabul modeli çerçevesinde incelenmesi. Muhasebe ve Vergi Uygulamaları Dergisi (MUVU)/Journal of Accounting and Taxation Studies (JATS), 12(1).

Parsad, B., Lewis, L. and Tice, P. (2008). Distance education at degree-granting postsecondary institutions: 2006-2007 (pp. 90-95). Washington, DC: National Center for Education Statistics, Institute of Education Sciences, US Department of Education.

Patton, M. Q. (2014). Nitel araştırma ve değerlendirme yöntemleri. (M. Bütün, ve S. B. Demir, Çev.). Pegem Akademi Yayınları.

Saban, A. (2004). Giriş düzeyindeki sınıf öğretmeni adaylarının "öğretmen" kavramına ilişkin ileri sürdükleri metaforlar. Türk Eğitim Bilimleri Dergisi, 2(2), 131-155.

Saban, A. (2008). Okula ilişkin metaforlar. Kuram ve Uygulamada Eğitim Yönetimi Dergisi, 14(3), 459-496.

Saban, A. (2009). Öğretmen adaylarının öğrenci kavramına ilişkin sahip oldukları zihinsel imgeler. Journal of Turkish Educational Sciences, 7(2).

Simonson, M., Smaldino, S., Albright, M. and Zvacek, S. (2012). Instructional design for distance education. Teaching and Learning at a Distance, 150-192.

Sönmez, V. ve Alacapınar, F. G. (2011). Örneklendirilmiş bilimsel araştırma yöntemleri [Exemplified scientific research methods]. ANI Yayıncllk.

Toprakçı, E. (2008). Sınıfa dayalı yönetim. Ankara: Pegem Akademi Yayınları.

Toprakçı, E. ve Ersoy, M. (2008) Uzaktan Öğretimde Öğretmen Rolleri II. Uluslararası Bilgisayar ve Öğretim Teknolojileri Sempozyumu (Sözel Bildiri). Ege Üniversitesi Eğitim Fakültesi 16-18 Nisan 2008 Kuşadası/IZMIR Erisim: https://www.erdaltoprakci.com.tr/wpcontent/uploads/2020/12/uzaktan-egitim-öğretmen-rolleri.pdf

Toprakçı, E.(2021) Değerlerli" Uzaktan Öğretim, Hürriyet Gazetesi, Eğitim Haberleri (04.01.2021), https://www.hurriyet.com.tr/egitim/degerlerli-uzaktan-ogretim-41705164

Türk Dil Kurumu, (2020). Online Türkçe Sözlük. http://www.tdk.gov.tr/index.php?option =com_gtsvearama $=$ gtsveguid $=$ TDK.GTS.5cca21 be0b54f3.43240071.

Yaman, E., Mermer, E. Ç. ve Mutlugil, S. (2009). Illköğretim okulu öğrencilerinin etik davranışlara ilişkin görüşleri: Nitel bir araştırma. Değerler Eğitimi Dergisi, 7(17), 93-108.

Yıldırım, A. ve Şimşek, H. (2013). Sosyal bilimlerde nitel araştırma yöntemleri. Seçkin Yayınevi.

Yıldırım, K. (2020). İstisnai bir uzaktan eğitim öğretim deneyiminin öğrettikleri. Alanyazın, 1(1), 7-15.

Yılmaz, M. (2020). Uzaktan eğitimin iyileştirilmesi: Salgın kaynaklı eğitim krizini aşmak için öneriler (Politika Notu: 2020/12). İLKE İlim Kültür Eğitim Vakfı.

Yob, I. M. (2003). Thinking constructively with metaphors. Studies in Philosophy and Education, 22, 127-138. 


\title{
Metaphoric Perceptions of University Students on Distance Education
}

\author{
Assistant Professor Nesip Demirbilek \\ Bingol University-Turkey \\ ndemirbilek@bingol.edu.tr
}

\begin{abstract}
This study aims to reveal how university students conceptualize their thoughts about distance education through metaphors. The phenomenological pattern, one of the qualitative research methods, was used in the study. Criterion sampling, one of the purposeful sampling methods, was used to determine the study group of the study. In the criterion sampling technique, individuals who are interested in the research subject and have knowledge are generally used in determining the participants. Being a university student subjected to distance education was determined as the basic criterion in the selection of the participants in this study. In line with the purpose of the study, a study group consisting of distance education university students who are knowledgeable about the research subject was determined. In the study group determined for this study, a total of 1449 university students, 508 from Mus Alparslan University and 941 from Bingol University, who studied distance education in the 2019-2020 academic year, were included. In the research, students were asked to complete the metaphor sentence. The "content analysis" technique was used in the analysis of the data obtained in the study. As a result of the research, university students produced 854 different metaphors about the concept of "distance education". These metaphors created by the students were categorized considering their similar aspects. According to the similarities of the metaphors formed by university students, 59 different codes and 2 separate categories as positive and positive were created. According to the results of the research, metaphors were mostly produced by the students under the code of "being inadequate" ( $f=68$ ). According to the findings of the research, it is suggested that distance education practitioners should install new skills and roles.
\end{abstract}

Keywords: University, Distance education, Metaphoric perception, University student

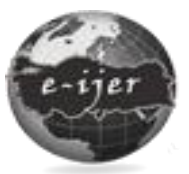

E-International Journal of Educational Research, Vol: 12, No: 1, 2021, pp. 1-15

DOI: 10.19160/ijer.786303

\section{Suggested Citation:}

Demirbilek, N. (2021). Metaphoric Perceptions of University Students on Distance Education. EInternational Journal of Educational Research, Vol: 12, No: 1, 2021, pp. 1-15, DOI:

10.19160/ijer.786303 


\section{EXTENDED ABSTRACT}

Problem: Distance education is a technological educational system established to enable students to continue their education processes at different times and places. According to another definition, it is defined as an open and blended learning environment in which pedagogical tools are used, activated by internet and web technologies, and facilitated by meaningful activities and interactions. Distance education is an education method that occurs due to various limitations of traditional education-training processes, where face-to-face education practices are not possible, it is carried out from certain centers, aims more people to learn on their own, educational contents are specially prepared for learners with special tools and different technological tools are used it is also defined as Distance education is simply a form of education in which the teacher and the learner do not physically coexist. In short, it can be summarized as a form of education that is carried out without being dependent on time and place.

The metaphor technique is a technique that determines what is what is meant to be explained using few words in the studies and facilitates the transformation of abstract concepts into the concrete. With the metaphor technique used in this study, it was tried to determine how students conceptualize the concept of distance education and what they liken it to, based on how students perceive the concept of distance education and transform it from abstract to concrete. For this reason, it is thought that this study will reveal important findings of how the concept of distance education is understood and filled by university students. In addition, what students understand from distance education is also very important in terms of determining their views on what their expectations are. It is anticipated that the results of this study will contribute to the studies for the development of new methods related to distance education.

When the distance education studies are examined in the literature, there is no study examining the perceptions of university students towards the mentioned concept. In this context, the aim of the study was determined as examining the metaphorical perceptions of university students regarding the concept of distance education. For this purpose, the research problem is, "What are the metaphorical perceptions of university students about distance education?" It was created in the form.

Method: In the study, as the meanings attributed to the concept of distance education were examined in depth in line with the opinions of university students, the phenomenological design, one of the qualitative research designs, was used. Phenomenology pattern is used to illuminate the cases that we are aware of but want to determine in-depth and with their reasons. Phenomenology: It is a research design that tries to understand more people's inner world and their consciousness structures. With phenomenology, we have the opportunity to examine in-depth the facts that are not familiar to us, but we do not have any information about their certainty and provide the opportunity to interpret with rich discourses. In this context, it is investigated how individuals perceive, explain, remember a phenomenon, and what kind of language they use to convey this phenomenon to people. In addition, metaphor analysis, which is an effective method for the in-depth investigation of complex concepts, events, and phenomena, is seen as an important qualitative research method.

Findings: As a result of the research, university students produced 854 different metaphors about the concept of "distance education". According to the similarities of the metaphors formed by university students, 59 different codes and 2 separate categories as positive and positive were created. According to the findings of the research, it is suggested that distance education practitioners should install new skills and roles. Most metaphors were produced in the code of "being inadequate". The subsequent metaphor codes are, respectively, "being inefficient" and "having continuity." The codes with the least metaphors were determined as "being complementary", "low cost" and "being addictive". 
When we look at all the negative codes, we can say that each code seriously disrupts the educational processes. It can be said that the codes evaluated as negative emphasize the errors in practice rather than the definition of distance education. According to the results of the study, distance education was perceived as insufficient due to its deficiencies and therefore emerged as the category that was most mentioned. It has been stated that these shortcomings cause educational processes to be inefficient and ineffective. In addition to these deficiencies, it has been observed that categories such as uncertain, incomprehensible, limited possibilities, complex, not learned, useless, volatile, cause an increase in inadequacy in education processes. Based on these data, it is thought that those who are authorized to improve the limited opportunities of university students in the first place and then eliminate their other deficiencies should be the intermediaries. 